\title{
Validity and Reliability of the Turkish Version of DSM-5 Level 2 Anxiety Scale (Child Form for 11-17 Years and Parent Form for 6-17 Years)
}

\author{
Şermin YALIN SAPMAZ ${ }^{10}$, Handan ÖZEK ERKURAN ${ }^{2} \mathbb{D}^{\circ}$, Dilay KARAARSLAN ${ }^{3} \mathbb{C}$, Masum ÖZTÜRK ${ }^{1}$, \\ Gülsüm YÖRÜK ÜLKER ${ }^{4} \oplus$, Burcu SERIM DEMIRGÖREN ${ }^{5}$, Ertuğrul KÖROĞLU ${ }^{6} \mathbb{D}$, Ömer AYDEMIR ${ }^{7}$ \\ 'Department of Child and Adolescent Psychiatry, Celal Bayar University, Faculty of Medicine, Manisa, Turkey \\ 2Department of Child and Adolescent Psychiatry, Dr. Behcet Uz Children's Hospital, Izmir, Turkey \\ ${ }^{3}$ Department of Child and Adolescent Psychiatry, Uşak State Hospital, Uşak, Turkey \\ ${ }^{4}$ Department of Psychology, Celal Bayar University, Faculty of Medicine, Manisa, Turkey \\ ${ }^{5}$ Department of Child and Adolescent Psychiatry, Dokuz Eylül University, Faculty of Medicine, İzmir, Turkey \\ ${ }^{6}$ Boylam Psychiatry Hospital, Ankara, Turkey \\ ${ }^{7}$ Department of Psychiatry, Celal Bayar University, Faculty of Medicine, Manisa, Turkey
}

\section{ABSTRACT}

Introduction: This study aimed to assess the validity and reliability of the Turkish Version of DSM-5 Level 2 Anxiety Scale's child and parent forms.

Methods: The scale was constructed by carrying out the translation and back translation of DSM-5 Level 2 Anxiety Scale. The study group consisted of a community and clinical sample. The scale was applied to 148 parents and 189 adolescents that represented the clinical and community sample. During the assessment process, Screen for Childhood Anxiety Related Emotional Disorders and Strengths and Difficulties Questionnaire - Parent Form were also used.

Results: Reliability analyses indicated a high internal consistency regarding Level 2 Anxiety Scales, both for child and parent forms
(0.915/0.933). In the meantime, it was shown that child form for Level 2 Anxiety Scale was significantly correlated with Screen for Childhood Anxiety Related Emotional Disorders $(r=0.758, p<0.0001)$ while the parent form was significantly correlated with Strengths and Difficulties Questionnaire - Parent Form ( $r=0.717, p<0.0001)$. As for the content validity, one factor was obtained for both forms, and it was observed to be consistent with the original construct of the scale.

Conclusion: It was concluded that Turkish version of DSM-5 Level 2 Anxiety Scale was a valid and reliable tool to be utilized both for clinical practice, and research purposes.

Keywords: Level 2 anxiety scale, reliability, validity

Cite this article as: Yalın Sapmaz \$̧, Özerk Erkuran H, Karaaslan D, Öztürk M, Yörük Ülker G, Serim Demirgören B, Köroğlu K, Aydemir Ö. Validity and Reliability of the Turkish Version of DSM-5 Level 2 Anxiety Scale (Child Form for 11-17 Years and Parent Form for 6-17 Years). Arch Neuropsychiatry 2018;55:152-156. https://doi. org/10.5152/npa.2017.15935

\section{INTRODUCTION}

As transient and mild anxiety is commonly observed during childhood and adolescence, anxiety disorders with severe symptomatology are not scarce. Multiple large scale epidemiological studies have reported that anxiety disorders are among the most commonly encountered disorders regarding adolescent psychopathologies. Prevalence rates with epidemiological studies have yielded lifetime prevalence rates up to $30 \%$ (1).

In studies conducted with adult samples or retrospectively, anxiety disorders are shown to be manifested with chronic course in general. Many studies conducted in children and adolescents have also yielded similar results. Children diagnosed with any anxiety disorder tend to have higher rates of being diagnosed with the same disorder, or any other anxiety disorder compared to their unaffected counterparts in adolescence, and even adulthood (2).

In a prospective study, it was shown that among adolescents that were diagnosed with anxiety disorder tend to have worse social adjustment, less coping skills, lower life satisfaction, more intrafamilial issues, low occupational satisfaction at 30 years of age (3). Again, it was seen that anxiety disorders during childhood and adulthood predicted the emergence of anxiety disorders, and also other psychiatric disorders. With Great Smoky Mountains study, which is a large scale community based study that followed up children into adulthood in USA, it was shown that anxiety disorders during childhood and adolescence predicted the emergence of anxiety, depression, and/or substance abuse during late adolescence or adulthood (4).

Despite high prevalence rates, anxiety disorders during childhood and adolescence mostly continue their course without being noticed, or treated (5). Early diagnosis and increasing chances to reach out for efficient treatment aid in better functioning throughout childhood, in turn decrease the possibility of continuum of the disorder into adulthood by causing improvement in negative effects of undiagnosed anxiety disorders. Practice Parameters of Assessment and Treatment

Correspondence Address: Şermin Yalın Sapmaz, Department of Child and Adolescent Psychiatry, Celal Bayar University, Faculty of Medicine, Manisa, Turkey

E-mail: drserminyalin@hotmail.com

Received: 17.02.2016, Accepted: 28.10.2016, Available Online Date: 04.05.2018

CCopyright 2016 by Turkish Association of Neuropsychiatry - Available online at www.noropskiyatriarsivi.com 
in Children and Adolescents with Anxiety Disorders have underlined the importance of developing evidence based tools for screening and evaluation to increase appropriate diagnostic procedures, and treatment options (6). In the meantime, it also recommends routine screening of anxiety symptoms, rating the severity and functional impairment of anxiety symptoms, assessment of comorbid situations, and a differential diagnostic process where other physical conditions and psychiatric pictures might mimic anxiety symptoms (6).

DSM has been released with its fifth edition. The new edition comprises anxiety disorders group as the most altered diagnostic category with respect to DSM-IV-TR. According to this edition, while trauma related disorders and obsessive compulsive disorder take place in separate categories, panic disorder, phobic disorders, social anxiety disorder, and generalized anxiety disorder form the anxiety disorders category. Separation anxiety disorder has also been added to this newly formed category (7). With their newly defined criteria and categories, novel assessment tools were warranted for evaluating these disorders. For this reason, new scales have been developed for measuring anxiety disorders (8).

DSM-5 Level 2 Anxiety Scale is a scale that determines the severity of anxiety disorder symptoms in children and adolescents. It has been designed to be utilized in the first evaluation and treatment processes of children and adolescents diagnosed with anxiety disorder (or have clinically severe anxiety symptoms) (8).

We aimed to assess the Turkish validity and reliability of DSM-5 Level 2 Anxiety Scale.

\section{METHODS}

\section{Translation Process}

To carry out the adaptation of DSM-5 Level 2 Anxiety Scale into Turkish, first, a written consent was obtained from HYB Yayıncılık and Boylam Psikiyatri Enstitüsü that held the publication and translation rights of DSM-5 Source Book and Handbook for scale studies. The translation was carried out by three child and adolescent psychiatry specialists. When the text was controlled and agreed upon, it was translated into English. The translated text was compared to the original, and was checked if it met the warranted criteria for the inclusion of expected concepts. When the necessary approval was maintained, the scale text was finalized.

\section{Sample Group}

For the sample of the study, healthy volunteers and patients that have been followed up in Celal Bayar University (CBÜ) Child Psychiatry Outpatient Unit, and their parents were included. Among groups, clinical sample that represented the high-risk group regarding psychiatric symptoms consisted of 31 adolescents aged between 11-17 years that have been followed up in CBÜ Medical School Child Psychiatry Outpatient Unit with the diagnosis of any anxiety disorder according to DSM-5 criteria. Diagnoses in the patient group were made by carrying out a semi structured clinical interview based on DSM-5 diagnostic classification system. Inclusion criteria were being 11-17 years of age, meeting the criteria for any anxiety disorder according to DSM-5, and having an intellectual functioning enough to follow the instructions of the study. Exclusion criteria were having a physical or a neurological disorder that would require continuous treatment. Members of community sample that represented the low-psychiatric risk group were recruited from neighborhood schools. To obtain an enough sample size, the study group needs to include a number of volunteers that would be 5-10 fold of the number for the scale's number of the items. For this reason, the number of students in the healthy group was determined as at least 130, and number of parents was determined as at least 100. Inclusion criteria for control group were being between 11-17 years of age, not meeting any criteria for a psychiatric or a physical disorder, and having enough intellectual capacity to follow the study instructions.

Ethical approval was given by Celal Bayar University Medical School Clinical Researches Evaluation Committee.

\section{Assessment Tools}

\section{DSM-5 Level 2 Anxiety Scale: Child form for 11-17 years and} Parent Form

This scale has a 10-item parent form filled out by parents or legal guardian for 6-17 years of age, and also a 13-item self report form for adolescents to fill out for themselves. Level 2 Anxiety Scale provides a five point Likert type assessment ( $1=$ never, $5=$ almost all the time). The scale was developed to be used for the first assessment, and follow-up of children and adolescents that were diagnosed with anxiety disorder (or that have clinically severe anxiety symptoms). For each item, the subject is asked to rate the severity of symptoms regarding anxiety disorders for the past 7 days. Higher scores reflect the presence of a much more severe anxiety disorder (8)

\section{Screen for Child Anxiety and Related Disorders (SCARED)}

The scale was developed by Birmaher et al. (1999) to screen anxiety disorders in childhood (9). SCARED has a parent and child form, and its Turkish validity and reliability study had been done by Cakmakci et al. in 2004. SCARED consists of 41 items in total, and scores of 25 and above indicate a warning for anxiety disorders. The scale also has subscales for somatic/panic, generalized anxiety, separation anxiety, social anxiety, and school anxiety (10).

\section{Strengths and Difficulties Questionnaire Parent Form-SDQ}

Strengths and Difficulties Questionnaire (SDQ) is a questionnaire utilized for screening psychiatric problems of children and adolescents. This questionnaire has a parent form for 4-16 years of age, and also a school form while it also has a separate adolescent self report form for youth between 11-16 years of age. The questionnaire contains 25 questions that interrogate some positive, and some negative behavioral features. The questions have been summed up under 5 subtitles that each contains five questions according to both appropriate diagnostic criteria, and factor analysis results; Attention Deficit and Hyperactivity, Conduct Problems, Emotional Problems, Peer Relationship problems, and Social Behavior. Each subtitle is assessed within itself, and separate scores could be derived as well as calculating a "Total Difficulty Score" by summing up first four titles. Emotional problems subscale includes mood symptoms, and anxiety symptoms (11).

\section{Statistical Analysis}

For statistical analysis, to show that there was no difference between study groups regarding sociodemographic and clinical features, variance analysis was applied (ANOVA) to numeric variables, and chi-square test was applied to categorical variables.

For reliability analyses, Cronbach alpha internal consistency analysis was carried out. In the meantime, the scale's reliability was proven by calculating item-total score correlation coefficients. In the analysis, Level 2 Anxiety Scale was reapplied to healthy 34 adolescents and 47 parents while calculating correlation coefficient between two applications 2 weeks after the initial one, determining test-retest reliability. Besides, 52 cases had both parent and self report form, and reliability between testors was measured.

To test the construct validity of the scale, explanatory factor analysis was applied by using data from all study groups. Firstly, to control if the 
sample was appropriate for exploratory analysis, Kaiser-Meier-Olkin Test and Bartlett Test were used. Explanatory factor analysis was carried out by applying Varimax rotation according to main compounds method, and factors equal to 1 and above were taken into account. Factor loads that are equal to 0.4 and above within factor constructs were taken into assessment. Explanatory factor construct was compared to that of the original dimension construct of the scale. In the meantime, correlations between Level 2 Anxiety Scale Child Form and Screen for Childhood Anxiety Disorders (SCARED), and between Level 2 Anxiety Scale Parent Form and Strengths and Difficulties Questionnaire Parent Form was evaluated.

\section{RESULTS}

A total of 148 parents and 189 adolescents were included in the study. Regarding parent sample, mean age for children that form the clinical group $(n=30$ ) was $13.7 \pm 2.1$ years while mean age for community sample was $13.9 \pm 1.8$ years. A total of parents of 20 girls and 10 boys in the clinical sample while parents of 70 girls and 48 boys had filled up the parent forms. In the adolescent sample, 20 girls and 10 boys from the clinical sample while 84 girls and 75 boys from the community sample have filled out the forms. Mean age of the clinical sample (n: 30$)$ in the adolescent group was $13.9 \pm 2.1$ years while $14.4 \pm 1.06$ years for community sample (n: 159$)$. Fifty-two cases had both parent and also child forms. Sociodemographic and clinical features of study groups (both adolescent sample and also parent samples) were presented in Table 1.

Statistically significant difference was found between patient group and control group regarding mother's educational status (chi-square $=25.159$, $p<0.0001$ ), father's educational status (chi-square=8.937, $p<0.0001$ ), DSM-5 Level 2 Anxiety Scale Child Form total score ( $T=7.037, p<0.0001)$, DSM-5 Level 2 Anxiety Scale Parent Form total score ( $T=8.603, p<0.0001)$, Strengths and Difficulties Questionnaire Parent Form Emotional Problems Subscale score $(T=8.546, p<0.0001)$, Screen for Childhood Anxiety Disorders total score $(T=7.276, p<0.0001)$. No significant difference was found between case and control group regarding age ( $T=1.091, p>0.05)$ and gender (chi-square $=1.901, \mathrm{p}>0.05$ ).

\section{Reliability analyses}

For the reliability analyses of DSM-5 Level 2 Anxiety Scale, Cronbach alpha internal consistency coefficient was found to be 0.915 for self report form, and 0.933 for parent form. Cronbach alpha coefficient for each item was shown in Table 2 and 3. Item-total score correlation coefficient was found between 0.347 and 0.762 for self report form while between 0.505 and 0.847 for parent form (Table 2 and 3). For test-retest application, data of 34 children and 47 parents were fit for analysis, and correlation coefficients between two weeks apart applications were $r=0.803(p<0.0001)$ for child form, and $r=0.615(p<0.0001)$ for parent form.

Correlation coefficient of DSM 5 Anxiety scale children and parent forms was found as $r=0.566(p<0.0001)$.

\section{Validity analyses}

To maintain construct validity, explanatory factor analysis was applied to DSM-5 Level 2 Anxiety Scale. Kaiser-Meyer-Olkin analysis and Bartlett Tests were applied to assess whether the sample group was in congruity or not, prior to explanatory factor analysis application.

The coefficient for DSM 5 Level 2 Anxiety Scale-Child Form KaiserMeyer-Olkin analysis was found as 0.926. As a result of Bartlett Test, chisquare value was calculated as $1251.226(p<0.0001)$ and it was shown that the sample was group was in congruity with factor analysis. As a result of factor analysis, one factor whose eigenvalue was 6.651 and that accounted for $50.5 \%$ of the variance was obtained. Factor loads were shown in Table 2.
Table 1. Sociodemographic features of the study groups

\begin{tabular}{|c|c|c|c|}
\hline & & $\begin{array}{c}\text { Anxiety } \\
\text { disorder group } \\
\mathrm{N}: \mathbf{3 1} \\
\end{array}$ & $\begin{array}{l}\text { Control } \\
\text { group } \\
\text { N: } 254 \\
\end{array}$ \\
\hline Age* & & $13.8 \pm 2.1$ & $14.25 \pm 1.4$ \\
\hline \multirow[t]{2}{*}{ Gender* } & Female & 21 (67.7\%) & 139 (54.7\%) \\
\hline & Male & $10(32.3 \%)$ & 115 (45.3\%) \\
\hline \multirow[t]{2}{*}{ School } & Attending & 31 (100\%) & 254 (100\%) \\
\hline & Not attending & 0 & 0 \\
\hline \multirow{3}{*}{$\begin{array}{l}\text { Mother's } \\
\text { educational } \\
\text { status }^{* *}\end{array}$} & $\begin{array}{l}\text { Primary \& secondary } \\
\text { school }\end{array}$ & 20 (64.5\%) & $61(24 \%)$ \\
\hline & High school & $8(25.8 \%)$ & $72(28.3 \%)$ \\
\hline & College & $3(9.7 \%)$ & 121 (47.6\%) \\
\hline \multirow{3}{*}{$\begin{array}{l}\text { Father's } \\
\text { educational } \\
\text { status** }\end{array}$} & $\begin{array}{l}\text { Primary \& secondary } \\
\text { school }\end{array}$ & $12(38.8 \%)$ & 49 (19.6\%) \\
\hline & High school & $11(35.5 \%)$ & $72(28.7 \%)$ \\
\hline & College & $8(25.8 \%)$ & 130 (51.8\%) \\
\hline \multirow{3}{*}{$\begin{array}{l}\text { Duration of } \\
\text { illness }\end{array}$} & New diagnosis & $5(16.1 \%)$ & \\
\hline & 1-6 months & 26 (83.9\%) & \\
\hline & Over 6 months & $0(\% 0)$ & \\
\hline \multirow[t]{3}{*}{ Medication } & Antidepressants & 26 (83.9\%) & \\
\hline & Antipsychotics & 1 (\% 3.2) & \\
\hline & Benzodiazepines & $0(\% 0)$ & \\
\hline \multirow[t]{4}{*}{$\begin{array}{l}\text { Scores of the } \\
\text { scales applied }\end{array}$} & $\begin{array}{l}\text { DSM } 5 \text { Anxiety Scale- } \\
\text { Child Form }\end{array}$ & $39.4 \pm 11.2$ & $24.1 \pm 8.9$ \\
\hline & $\begin{array}{l}\text { DSM } 5 \text { Anxiety Scale- } \\
\text { Parent Form** }\end{array}$ & $30.3 \pm 8.9$ & $15.6 \pm 6.1$ \\
\hline & SCARED** & $42.5 \pm 14.7$ & $22.8 \pm 13.3$ \\
\hline & $\begin{array}{l}\text { SDQ Emotional } \\
\text { Problems Subscale ** }\end{array}$ & $5.3 \pm 2.2$ & $1.9 \pm 1.9$ \\
\hline
\end{tabular}

${ }^{*} p>0.05 ;{ }^{* *} p<0.0001$

Kaiser-Meyer-Olkin analysis coefficient for DSM-5 Level 2 Anxiety ScaleParent Form was calculated as 0.931. Chi-square with Bartlett Test was calculated as $1023.394(p<0.0001)$ and it was shown that the sample group was congruent for factor analysis. As a result of factor analysis, one factor with an eigenvalue as 6.260 and that had accounted $62.6 \%$ of the total variance was obtained. Factor loads were shown in Table 3.

As a result of concurrent validity analysis of DSM-5 Level 2-Anxiety ScaleChild Form with SCARED, the correlation coefficient was calculated as $r=0.758, p<0.0001$.

As a result of concurrent validity analysis of DSM 5 Level 2 Anxiety ScaleParent Form with SDQ's Emotional Symptoms subscale, correlation coefficient was calculated as $r=0.717, p<0.0001$.

\section{DISCUSSION}

With this study, validity and reliability of Turkish adaptation for DSM-5Level 2 Anxiety Scale child and parent forms were evaluated, and it was shown that Turkish version could be utilized. 
Table 2. Cronbach alpha values, item-total score correlation coefficients, factor loads of items of DSM 5 Level 2 Anxiety Scale-Child Form

\begin{tabular}{|l|c|c|c|}
\hline & $\begin{array}{c}\text { Cronbach } \\
\text { alpha values }\end{array}$ & $\begin{array}{c}\text { Item-total score } \\
\text { correlation } \\
\text { coefficients }\end{array}$ & Factor loads \\
\hline Anxiety 1 & 0.906 & 0.707 & 0.758 \\
\hline Anxiety 2 & 0.914 & 0.509 & 0.568 \\
\hline Anxiety 3 & 0.904 & 0.754 & 0.809 \\
\hline Anxiety 4 & 0.906 & 0.691 & 0.742 \\
\hline Anxiety 5 & 0.907 & 0.686 & 0.745 \\
\hline Anxiety 6 & 0.905 & 0.731 & 0.786 \\
\hline Anxiety 7 & 0.905 & 0.753 & 0.812 \\
\hline Anxiety 8 & 0.918 & 0.347 & 0.404 \\
\hline Anxiety 9 & 0.911 & 0.562 & 0.632 \\
\hline Anxiety 10 & 0.910 & 0.594 & 0.664 \\
\hline Anxiety 11 & 0.907 & 0.681 & 0.746 \\
\hline Anxiety 12 & 0.911 & 0.571 & 0.636 \\
\hline Anxiety 13 & 0.903 & 0.762 & 0.813 \\
\hline
\end{tabular}

Table 3. Cronbach alpha values, item-total score correlation coefficients, factor loads of items of DSM 5 Level 2 Anxiety ScaleParent Form

\begin{tabular}{|l|c|c|c|}
\hline & $\begin{array}{c}\text { Cronbach } \\
\text { alpha values }\end{array}$ & $\begin{array}{c}\text { Item-total score } \\
\text { correlation } \\
\text { coefficients }\end{array}$ & Factor loads \\
\hline Anxiety 1 & 0.927 & 0.722 & 0.779 \\
\hline Anxiety 2 & 0.928 & 0.697 & 0.757 \\
\hline Anxiety 3 & 0.922 & 0.823 & 0.864 \\
\hline Anxiety 4 & 0.921 & 0.847 & 0.884 \\
\hline Anxiety 5 & 0.923 & 0.794 & 0.841 \\
\hline Anxiety 6 & 0.926 & 0.743 & 0.798 \\
\hline Anxiety 7 & 0.922 & 0.829 & 0.870 \\
\hline Anxiety 8 & 0.936 & 0.505 & 0.572 \\
\hline Anxiety 9 & 0.929 & 0.689 & 0.748 \\
\hline Anxiety 10 & 0.929 & 0.690 & 0.751 \\
\hline
\end{tabular}

Many scales are present to be used during the assessment of anxiety disorders. Some of these scales screen general psychopathology such as Strengths and Difficulties Questionnaire that also contain sub items for anxiety symptoms (11). Also there are also scales that assess anxiety symptoms only. Among scales that assess specifically anxiety disorders, Turkish validity and reliability studies have been made for SCARED - Child Form, State and Trait Anxiety Inventory for Children, Spence Anxiety Scale for Children - Parent Form, and Revised Anxiety Report Form for Children (10-14). Spence Anxiety Scale-Parent Form has only been studied in community samples in our country. The internal consistency of the scale was 0.88 . Item-total score correlation coefficients were found between 0.15 and 0.52 . As a result of factor analysis, it was determined that Turkish version of the scale was not in congruity with the original construct of the scale. Besides, concurrent validity was not assessed in the abovementioned study (13). Cronbach alpha value of the Turkish version of State and Trait Anxiety Inventory for Children was found as 0.82 . Correlation coefficient was found to be 0.65 as a result of test-retest application (12). Revised Anxiety Scale for Children's 10-item short form's Cronbach alpha value was 0.70 . Its test-retest reliability coefficient was 0.96. As for concurrent validity, correlation with State and Trait Anxiety Inventory for Children was assessed and correlation with trait inventory was found to be 0.71 while 0.09 with state inventory (14).

During assessment of adolescents for anxiety disorders, it is a major contribution for resolving the problem to gather information from different sources; such as the adolescent himself/herself, the family, and teachers when necessary (15). The presence of both parent and child forms of DSM 5 Level 2 Anxiety Scale might provide an advantage regarding this fact. Earlier studies indicate that correlation between the data obtained from the parents and the child is low for psychiatric complaints. In a meta-analysis derived from this problem, the rate was calculated as 0.25 (16). In studies conducted with SCARED, the correlation coefficient was reported to be between 0.30 and 0.40 with respect to the correlation of total scores of parents and children $(17,18)$. The correlation coefficient between the parent form and child form was found to be in high levels $(0.566, p<0.0001)$ and statistically significant. This supports the reliability of the scale.

In our study, Cronbach alpha coefficient for internal consistency for both child and parent forms were high (0.915/0.933), and this indicates that the scale can appropriately represent the whole construct. It is warranted that item-total score correlation coefficient would be above 0.2 for each item (19). While Level 2 anxiety scale's item-total score correlation coefficients were of medium levels for 8th item in child form, coefficients for all other items for child and parent form were found as high and very high levels, and prove that the construct of the scale is reliable. Correlation coefficients between test-retest applications were 0.803 for child form, and 0.615 for parent form, both indicating a high level and statistical significance. When all these results are taken into consideration, it could be postulated that the scale could be used as a reliable tool.

As for concurrent validity analysis, correlations between child form and SCARED, while between parent form and SDQ Emotional Problems subscale were assessed and calculated as 0.758 and 0.717 , respectively. These values indicate high levels, and are statistically significant. Concurrent validity of the scale supports the valid use of the scale.

Explanatory factor analysis was applied to DSM Level 2 Anxiety Scale. To have significance in factor analysis, and to be taken into evaluation, the 'eigenfactor' value needs to be above 1. Besides, factor loads need to be over 0.4 to each item with factor load to be significant. Among factors with significance, they are expected to explain for at least $40 \%$ of the variance (19). In our study, one factor with 'eigenfactor' value above 1 was obtained for each form and is in congruity with the original construct of the scale. The conceptualization of anxiety disorder symptoms in a single factor construct make the scale become much more specific to the anxiety disorder symptom cluster. By this way, the clinician might have clearer information regarding the severity of anxiety disorder without confounding factors.

\section{Limitations and Advantages of the Study}

Primary limitation to this study was the relatively low number of the sample group where the patients would have to be consisted of individuals within the symptomatic phase. Another limitation was the lack of a structured clinical interview for the control group to determine diagnoses. In the meantime, the presence of a significant difference between patient and control groups regarding parental education 
statuses has to be taken into consideration when evaluating differences obtained in comparative analyses for items of the scale. The study's aim was that all statistical analyses could be carried out without any outage in the sample with the given size. The superiority of this study might be the sample size being representative for patients; by this way the clinical utility of the scale was proven.

\section{CONCLUSION}

As a result, these findings indicate that Turkish Form of DSM-5 Level 2 Anxiety Scale could be used as a valid and reliable tool both in clinical practice, and for research purposes.

Committee Approval: Ethical approval was given by Celal Bayar University Medical School Clinical Researches Evaluation Committee.

Informed Consent: Written informed consent form was obtained from all patients.

Peer-review: Externally peer-reviewed.

Author Contributions: Concept - ÖA, EK; Design - ÖA, EK, ŞYS; Supervision - ÖA, EK; Resource - DK, BSD, MÖ, GYÜ; Materials - DK, BSD, GYÜ, MÖ; Data Collection and/ or Processing - DK, BSD, GYÜ, MÖ; Analysis and/or Interpretation - ÖA, ŞYS, HÖE; Literature Search - ŞYS, HÖE, MÖ; Writing - ŞYS, HÖE; Critical Reviews - ÖA.

Conflict of Interest: No conflict of interest was declared by the authors.

Financial Disclosure: The authors declared that this study has received no financial support.

\section{REFERENCES}

1. Merikangas KR, He JP, Burstein M, Swanson SA, Avenevoli S, Cui L, Benjet C, Georgiades K, Swendsen J. Lifetime prevalence of mental disorders in U.S. adolescents: results from the National Comorbidity Survey Replication -Adolescent Supplement (NCS-A). J Am Acad Child Adolesc Psychiatr 2010;49:980-989. [CrossRef]

2. Bittner A, Egger HL, Erkanlı A, Jane Costello E, Foley DL, Angold A. What do childhood anxiety disorders predict? J Child Psychol Psychiatry 2007;48:1174-1183. [CrossRef]

3. Essau CA, Lewinsohn PM, Olaya B, Seeley JR. Anxiety disorders in adolescents and psychosocial outcomes at age 30. J Affect Disord 2014;163:125-132. [CrossRef]
4. Asselmann E, Beesdo-Baum K. Predictors of the course of anxiety disorders in adolescents and young adults. Curr Psychiatry Rep 2015;17:7. [CrossRef]

5. Chavira DA, Stein MB, Bailey K, Stein MT. Child anxiety in primary care: prevalent but untreated. Depress Anxiety 2004;20:155-164. [CrossRef]

6. Connolly SD, Bernstein GA; Work Group on Quality Issues. Practice parameter for the assessment and treatment of children and adolescents with anxiety disorders. J Am Acad Child Adolesc Psychiatry 2007;46:267-283. [CrossRef]

7. Amerikan Psikiyatri Birliği. Ruhsal Bozuklukların Tanısal ve Sayımsal Elkitabı, 5. Baskı (DSM-5). Tanı Ölçütleri Başvuru Elkitabı (Köroğlu E, çeviri editörü). Hekimler Yayın Birliği, Ankara, 2013

8. American Psychiatric Association (APA). Online Assessment Measures. Available at: http://www.psychiatry.org/practice/dsm/dsm5/onlineassessment-measures

9. Birmaher B, Brent DA, Chiapetta L, Bridge J, Monga S, Baugher M. Psychometric properties of the screen for Child Anxiety Related Emotional Disorders (SCARED): a replication study. J Am Acad Child Adolesc Psychiatry 1999;38:1230-1236. [CrossRef]

10. Çakmakçı FK. Çocuklarda anksiyete bozukluklarını tarama ölçeği geçerlik ve güvenirlik çalışması. Yayınlanmamış uzmanlık tezi, Kocaeli Üniversitesi Tıp Fakültesi, Kocaeli 2004.

11. Güvenir T, Özbek A, Baykara B, Arkar H, Şentürk B, İncekaş S. Psychometric Properties of the Turkish Version of the Strengths and Difficulties Questionnaire (SDQ). Turk J Child Adolesc Ment Health 2008;15:65-74.

12. Özusta Ş. Çocuklar için Durumluk-Sürekli Kaygı Envanteri Uyarlama, Geçerlik ve Güvenirlik Çalışması. Türk Psikoloji Dergisi 1995;10:32-44.

13. Orbay Ö, Ayvaşık HB. Spence Çocuklar için Kaygı Ölçeği-Ebeveyn Formu: Ön Çalışma. Türk Psikoloji Yazıları 2006;9:33-48.

14. Çölümlü GM. Çocuklar İçin Yenilenmiş Kaygı Ölçeği Türkçe Versiyonunun psikometrik özellikleri. Yayınlanmamış tez, 2014.

15. Mohr C. Schneider S. Anxiety disorders. Eur Child Adolesc Psychiatry 2013;22(Suppl 1):S17-S22. [CrossRef]

16. Achenbach TM, McConaughy SH, Howell CT. Child/adolescent behavioral and emotional problems: implications of cross-informant correlations for situational specificity. Psychol Bull 1987;101:213-232.

17. Muris $P$, Merckelbach $H$, van Brakel A, Mayer B. The revised version of the screen for child anxiety related emotional disorders (SCARED-R): further evidence for its reliability and validity. Anxiety, Stress \& Coping: An International Journal 1999:12;411-425. [CrossRef]

18. Naut MH, Scholing A, Rapee RM, Abbott M, Spence SH, Waters A. A parent-report measure of children's anxiety: psychometric properties and comparison with child-report in a clinic and normal sample. Behav Res Ther 2004;42:813-839.

19. Köroğlu E, Aydemir Ö, Türkçapar H. Psikiyatride Araştırma Tasarımı, Yönetimi ve Denetimi. Ankara: HYB Yayıncılık; 2012. 